\title{
Cellulose-degrading enzyme production by Clonostachys byssicola: Partial purification and characterization of an endoglucanase
}

\author{
Sciuto DL ${ }^{1}$, Almeida RM$^{2}$, Miller RNG ${ }^{2}$, Moreira LRS $^{1}$, Filho $_{\text {EXF }}{ }^{{ }^{*}}$ \\ ${ }^{1}$ Enzymology Laboratory, Cellular Biology Department, University of Brasília, Brasília, DF, Brazil, CEP 70910-900 \\ ${ }^{2}$ Microbiology Laboratory, Department of Cell Biology, University of Brasília, Brasília, DF, Brazil, CEP 70910-900
}

Sciuto DL, Almeida RM, Miller RNG, Moreira LRS, Filho EXF 2017 - Cellulose-degrading enzyme production by Clonostachys byssicola: Partial purification and characterization of an endoglucanase. Mycosphere 8(3) 415-431, Doi 10.5943/mycosphere/8/3/4

\begin{abstract}
Agro-industrial wastes offer potential as renewable carbon sources for microbial growth and industrial enzyme production, with potential applications in textile and biofuel industries, among others. The filamentous fungus Clonostachys byssicola was cultivated for seven days in liquid medium containing $1 \%(\mathrm{w} / \mathrm{v})$ soybean hulls as unique carbon source. Hemicellulase, cellulase and pectinase activities were observed in the crude extract after seven days growth. A CMCase, denominated $\mathrm{Cb}$-Cel, was partially purified using ultrafiltration and chromatographic methods. With a molecular weight of $48 \mathrm{kDa}$, the enzyme was most active at $70^{\circ} \mathrm{C}$ and $\mathrm{pH} 5.0$, and thermostable at 40 and $50^{\circ} \mathrm{C}$. Cb-Cel showed $\mathrm{K}_{\mathrm{m}}$ and $\mathrm{V}_{\max }$ values of $15.81 \pm 1.65 \mathrm{mg} / \mathrm{mL}$ and 0.59 $\pm 0.03 \mathrm{IU} / \mathrm{mL}$, respectively. Phenolic compounds (tannic, 4-hydroxybenzoic, ferulic, $\rho$-coumaric, cinnamic acids and vanillin) had no inhibitory or deactivator effects on enzymatic activity when tested on the concentrated fraction or $\mathrm{Cb}$-Cel. Enzymatic hydrolysis of CMC and filter paper hydrolysis resulted in the release of glucose, cellopentaose and cellohexaose. Enzymatic hydrolysis of soybean hulls released mostly cellohexaose, cellopentase, mannose and xylobiose. In comparison to hydrolysis of sugarcane bagasse, the hydrolysis of soybean hulls yielded higher amounts of reducing sugars, suggesting that the enzymes secreted during growth of $C$. byssicola are more active on this substrate as carbon source.
\end{abstract}

Keywords - Cellulase - Enzymatic Hydrolysis - Phenolic Compounds - Soybean Hulls

\section{Introduction}

Concern over the depletion of fossil fuel resources and climate change attributed to anthropogenic carbon dioxide emissions has led to considerable global interest in the exploitation of renewable and carbon-neutral energy sources (Doherty et al. 2011). Among available energy sources, non-food lignocellulosic residues such as sugarcane bagasse, corn cob, soybean hulls, oat hulls and sorghum straws offer considerable potential as renewable carbon-sources.

Soybean hull, a by-product in processing, is an external layer of the grain that constitutes approximately $8 \%$ of the whole seed (Gnanasambandan \& Proctor 1999). Processed soybean is the world's largest source of animal protein feed and the second largest source of vegetable oil (USDA 2015). Considering the scale of global production, residues from this crop are expressive in volume, 
and offer potential as growth substrates for lignocellulolytic microorganisms and subsequent production of industrial enzymes.

Lignocellulosic biomass is highly recalcitrant to enzymatic degradation, which hinders enzyme access to the biomass. For this reason, the application of a biomass-disrupting pretreatment is often employed to increase enzyme access. Many of the pretreatments employed are performed under conditions that result in the formation of phenolic compounds from the degradation of lignin, which can have inhibitory effects on enzymes and/or fermentative organisms (Ximenes et al. 2010, Li et al. 2014). Efficient enzyme hydrolysis and reduced enzyme loading therefore depends upon a reduction of inhibition or deactivation effects on enzymes (Duarte et al. 2012).

The biotechnological application of fungal enzymes for agricultural waste degradation adds value to raw materials in an environmentally friendly manner (Siqueira 2010). Microbial cellulases are employed in the food, pulp and paper, feed and textile industries, as well as in the formulation of detergents and washing powders (Bhat 2000). In addition, these enzymes can be applied in the hydrolysis of lignocellulosic biomass to bioethanol, contributing towards sustainable development. Enzymatic hydrolysis of lignocellulosic biomass is considered as the most efficient and least polluting method for glucose production (Singhania et al. 2015). Endoglucanases act randomly on soluble and insoluble cellulose chains, releasing oligomers that will be attacked by cellobiohydrolases and liberating cellobiose. Cellobiose is subsequently converted to glucose by $\beta$ glucosidase (Moreira et al. 2011), with glucose then converted to ethanol by fermenting microorganisms. Considering that enzymatic hydrolysis followed by fermentation is the principal approach employed for second generation ethanol production from lignocellulosic biomass (Olofsson et al. 2008), there is increasing interest in the characterization of efficient enzymes for use in such applications.

The fungus Clonostachys byssicola, as well as its teleomorph Bionectria byssicola, is commonly found in neotropical regions. Although this fungus is known for its potential as a biological control agent against plant pathogenic fungi such as Moniliophthora roreri and Rosellinia spp. (Evans et al. 2003, García et al. 2003, Hoopen et al. 2003, Krauss et al. 2006, Alvindia \& Natsuaki 2008), there are no reports focusing on its ability to produce lignocellulosedegrading enzymes, including cellulase. In this study, we employed soybean hull lignocellulosic biomass as a carbon source for the submerged cultivation of C. byssicola and production of cellulolytic enzymes. To the best of our knowledge, this is the first report on the production and characterization of cellulases in C. byssicola.

\section{Materials and methods}

\section{Molecular characterization}

The fungal isolate was identified through molecular characterization. For molecular identification, genomic DNA was extracted using a phenol-chloroform-based protocol. The ITS region of the rRNA gene was amplified using the forward primers ITS1 (5' TCCGTAGGTGAACCTGCGG - 3') or ITS5 (GGAAGTAAAAGTCGTAACAAGG) and the reverse primer ITS4 (5TCCTCCGCTTATTGATATGC 3 (White et al. 1990). The $\beta$-tubulin gene was amplified using the forward primer Bt2a (GGTAACCAAATCGGTGCTGCTTTC) and reverse primer Bt2b (5' ACCCTCAGTGTAGTGACCCTTGGC 3') (Glass \& Donaldson. 1995). Each PCR reaction contained $10 \mathrm{ng}$ of genomic DNA, $0.4 \mu \mathrm{M}$ of each primer, $200 \mu \mathrm{M}$ dNTPs, $1.5 \mathrm{mM}$ $\mathrm{MgCl}_{2}, 1.0 \mathrm{U}$ Taq DNA polymerase and $1 \times$ IB Taq polymerase buffer (Phoneutria, Belo Horizonte, MG, Brazil). Thermocycling was conducted with the following program: denaturation at $95^{\circ} \mathrm{C}$ for 4 min, 30 cycles of denaturation at $94^{\circ} \mathrm{C}$ for $1 \mathrm{~min}$, primer annealing at $50^{\circ} \mathrm{C}$ for $1 \mathrm{~min}$, and extension at $72^{\circ} \mathrm{C}$ for $1 \mathrm{~min}$, plus a final elongation period at $72^{\circ} \mathrm{C}$ for $5 \mathrm{~min}$. All PCR products were purified using ExoSAP-IT® (USB, Cleveland, Ohio, USA) and forward and reverse- sequenced using the Big Dye ${ }^{\circledR}$ Terminator v3.1 Cycle Sequencing kit (Applied Biosystems, Foster City, CA, USA). PCR products were run on an ABI 3700 DNA sequencer (Applied Biosystems, Foster City, CA, 
USA). The sequences were then compared with the sequences in the NCBI nucleotide database using the BLAST algorithm (Altschul et al. 1997).

\section{Chemicals}

All substrates were purchased from Sigma Chemical Co. (St. Louis, MO, USA). Soybean hulls and sugar cane bagasse were obtained from a local source. Sephacryl S100, Q-Sepharose and DEAE-Sepharose columns were acquired from GE Healthcare Life Sciences, (Piscataway, NJ. USA). CarboPac PA-100 columns were purchased from Dionex Co. (Sunnyvale, CA, USA). Saccharides were purchased from Megazyme Co. (Wicklow, Ireland).

\section{Residue pretreatment}

Soybean hulls and sugarcane bagasse were thoroughly washed with tap water and autoclaved at $121^{\circ} \mathrm{C}$ for $2 \mathrm{~h}$. Material was subsequently dried at $60^{\circ} \mathrm{C}$ for $48 \mathrm{~h}$ and ground to form a homogeneous blend. The fine powder obtained was used as carbon source for fungal growth and substrate for analysis of enzymatic hydrolysis.

\section{Organism and enzyme production}

C. byssicola was obtained from the fungal culture collection at the Enzymology Laboratory, University of Brasília, Brazil (under genetic heritage number 010237/2015-1 for authorization to access and ship sample components). Following maintenance and growth on PDA medium (10\% potato broth, $1 \%$ dextrose and $2 \%$ agar), spore concentrations were determined under microscopy using a Neubauer chamber. Spore concentrations were adjusted with sterile saline solution $(0.9 \%)$ and $3 \mathrm{~mL}$ aliquots of spore suspensions $\left(10^{7}\right.$ spores $\left./ \mathrm{mL}\right)$ inoculated into Erlenmeyer flasks containing $300 \mathrm{~mL}$ of liquid medium $\left(0.7 \% \mathrm{KH}_{2} \mathrm{PO}_{4}, 0.2 \% \mathrm{~K}_{2} \mathrm{HPO}_{4}, 0.01 \% \mathrm{MgSO}_{4} \cdot 7 \mathrm{H}_{2} \mathrm{O}, 0.01 \%\right.$ $\left(\mathrm{NH}_{4}\right)_{2} \mathrm{SO}_{4}$, and $0.06 \%$ yeast extract) at $\mathrm{pH} 7.0$ with $1.0 \%(\mathrm{w} / \mathrm{v})$ soybean hulls as carbon source. The fungus was grown for 7 days at $28^{\circ} \mathrm{C}$ under agitation at $120 \mathrm{rpm}$. The medium was then filtered through filter paper and the resulting filtrate, hereafter called crude extract, used as source of enzymes.

\section{Enzyme assays}

Endoglucanase (CMCase), mannanase, pectinase and xylanase activities were determined by mixing $5 \mu \mathrm{L}$ of enzyme sample with $10 \mu \mathrm{L}$ of substrate $(4 \%$ (w/v) carboxymethylcellulose (CMC), $1 \%$ galactomannan, $1 \%$ pectin and $1 \%$ oat spelt xylan, respectively) at $50^{\circ} \mathrm{C}$ for $30 \mathrm{~min}$ (Salles et al. 2000, with modifications). The substrates were diluted in $100 \mathrm{mM}$ sodium acetate buffer ( $\mathrm{pH}$ 5.0). FPase activity was determined through incubation of $150 \mu \mathrm{L}$ of enzyme with a $1 \mathrm{x}$ $6 \mathrm{~cm}$ strip of filter paper (Whatman No. 1) at $50^{\circ} \mathrm{C}$ for $1 \mathrm{~h}$ (Mandels et al. 1976). The amount of reducing sugar released was measured using the DNS method (Miller 1959). Activity was expressed as $\mu \mathrm{mol}$ of reducing sugars formed per min per $\mathrm{mL}$ (IU/mL). Glucose, mannose, galacturonic acid and xylose were used as standards. Protein concentration was determined by the Bradford assay (1976) using bovine serum albumin as a standard. Glucose content was measured by the glucose oxidase method (Trinder 1969).

\section{Partial purification of CMCase}

Partial purification steps were carried out at room temperature. Crude extract of $C$. byssicola was concentrated 10 times by ultrafiltration using an Amicon System (Amicon Inc., Beverly, MA. USA) fitted with a $10 \mathrm{kDa}$ (PM 10) cut-off-point membrane. Aliquots (10 mL) of the concentrated samples were fractionated by gel filtration chromatography on a Sephacryl S100 $(3.0 \times 68.2 \mathrm{~cm})$ column, pre-equilibrated with $50 \mathrm{mM}$ sodium acetate buffer, pH 5.0 and $0.15 \mathrm{M} \mathrm{NaCl}$. Fractions of $5 \mathrm{~mL}$ were collected at a flow rate of $20 \mathrm{~mL} / \mathrm{h}$. Fractions $48-52$ with higher CMCase activity were pooled and subjected to ion-exchange chromatography on a HiTrap Q Sepharose Fast Flow (1 mL) column coupled to a purification Äkta system (GE Healthcare). The column was previously equilibrated with $50 \mathrm{mM}$ sodium acetate buffer, $\mathrm{pH}$ 5.0, followed by a linear gradient of $\mathrm{NaCl}(0-1$ M). Fractions (5 and 6) of $1 \mathrm{~mL}$ were collected at a flow rate of $1 \mathrm{~mL} / \mathrm{min}$. Fractions with CMCase 
activity were pooled and applied onto a HiTrap DEAE Sepharose Fast Flow column under the same conditions as described above. Fraction number 5 was collected and named $\mathrm{Cb}-\mathrm{Cel}$. All samples were stored at $4^{\circ} \mathrm{C}$.

\section{Electrophoresis and zymography}

Samples were precipitated with 10\% TCA (trichloroacetic acid) and washed three times with cold $100 \%$ acetone. Sodium dodecyl sulfate-polyacrylamide gel electrophoresis (SDS-PAGE) was carried out as described by Laemmli (1970) using a 12\% (w/v) gel, subjected to $25 \mathrm{~mA}$ for 50 min. The gel was stained for proteins using silver nitrate according to the method of Blum et al. (1987). Identification of CMCase activity was carried out by zymography, in which the substrate CMC was copolymerized in the polyacrylamide gel $(12 \% \mathrm{w} / \mathrm{v})$ in a final concentration of $0.4 \%$ (v/v). The gel was incubated at $60^{\circ} \mathrm{C}$ for $90 \mathrm{~min}$ and stained with Congo red $(0.1 \% \mathrm{w} / \mathrm{v})$ as described by Bischoff et al. (1998).

\section{Determination of hydrolysis products}

Reactions containing enzymatic fractions (concentrated and $\mathrm{Cb}-\mathrm{Cel}$ ) and substrates (soybean hulls, sugarcane bagasse, avicel, mannan and xylan (1\%) CMC (1\% and 4\%) and filter paper were incubated at $40^{\circ} \mathrm{C}$ under agitation at $120 \mathrm{rpm}$. Soybean hulls and sugarcane bagasse were incubated for 240 hours (aliquots were harvested initially every $24 \mathrm{~h}$ ), while avicel, mannan, xylan and CMC were incubated during 48 hours (aliquots were harvested every $12 \mathrm{~h}$ ). Aliquots of $125 \mu \mathrm{L}$ were withdrawn at intervals for quantification of total reducing sugars using the DNS method, for glucose quantification by the glucose oxidase method (Trinder 1969) and for analysis of hydrolysis products by high-performance anion exchange chromatography coupled with pulsed amperometric detection (HPAEC-PAD) (Ryan et al. 2003). In this process, aliquots (100 $\mu \mathrm{L})$ of hydrolysate samples were analyzed by HPAEC-PAD on a Dionex ICS 3000 Ion Chromatography DC System (Dionex Co., California, USA) using a CarboPac PA-100 column and guard column at $20^{\circ} \mathrm{C}$, with an operating flow rate of $0.25 \mathrm{~mL} / \mathrm{min}$. Samples were eluted for $80 \mathrm{~min}$ in $100 \mathrm{mM}$ sodium hydroxide solution (Sigma-Aldrich) and a gradient of $0-500 \mathrm{mM}$ sodium acetate (Merck) with $100 \mathrm{mM} \mathrm{NaOH}$. The reducing sugars were identified and quantified on an ED40 electrochemical detector (Dionex Co.), and the data analyzed by Chromeleon 6.8 SR8 (Dionex Co.). Oligossaccharide solutions with a degree of polymerization from 2 to 6 units (G2, cellobiose; G3; cellotriose; G4, cellotetraose; G5, cellopentaose; G6, cellohexaose; M2, mannose; M3, manotriose; M4, manotetraose; M5, manopentaose; M6, manohexaose; X2, xylobiose; X3, xylotriose; X4, xylotetraose; X5, xylopentaose; X6, xylohexaose) (Megazyme Co.) and glucose (G1), mannose (M1) and xylose (X1) (Sigma-Aldrich) were used as standards for analysis of the reaction products.

\section{Enzymatic characterization}

The effect of temperature on CMCase activity was determined by performing the standard assay at a temperature range of $30-80^{\circ} \mathrm{C}\left(\Delta=10^{\circ} \mathrm{C}\right)$ and $\mathrm{pH} 5.0$. The effect of $\mathrm{pH}$ on cellulase activity was determined at $50^{\circ} \mathrm{C}$ over a $\mathrm{pH}$ range of 3.0 to 9.0 , using the following buffers $(50$ $\mathrm{mM})$ : sodium acetate $(\mathrm{pH} 3.0-6.0)$, sodium phosphate $(\mathrm{pH} \mathrm{6.0-7.5)}$ and Tris- $\mathrm{HCl}(\mathrm{pH}$ 7.5-9.0). The evaluation of CMCase thermostability was performed by pre-incubating the enzyme samples at 40,50 and $60^{\circ} \mathrm{C}$. At various time periods, aliquots were taken and the residual activity measured under standard conditions.

The effect of phenolic compounds (vanillin, tannic acid, 4-hydroxybenzoic acid, ferulic acid, $\rho$-coumaric acid and cinnamic acid, at $1 \mathrm{mg} / \mathrm{mL}$ ) on CMCase activity was assessed by preincubating enzyme samples at $25^{\circ} \mathrm{C}$ in the presence of these compounds. Incubation was carried out for 7 days, and aliquots were taken for measurement of residual CMCase activity by the standard protocol. Appropriate controls were included for all experiments, and the average values were reported as relative activity $(\%)$. 
The effect of metal ions $\left(\mathrm{Ca}^{2+}, \mathrm{Co}^{2+}, \mathrm{Cu}^{2+}, \mathrm{Fe}^{2+}, \mathrm{Fe}^{3+}, \mathrm{K}^{+}, \mathrm{Mg}^{2+}, \mathrm{Na}^{+}, \mathrm{Zn}^{2+}\right)$ and EDTA (ethylenediaminetetraacetic acid), at concentrations of $1 \mathrm{mM}$ and $10 \mathrm{mM}$, on CMCase activity was evaluated by pre-incubating the enzyme samples at $25^{\circ} \mathrm{C}$ for $20 \mathrm{~min}$ in the presence of these compounds. The residual activity was determined using standard protocols.

For kinetics experiments, CMC concentration ranged from 0.5 to $26.7 \mathrm{mg} / \mathrm{mL}$. $\mathrm{K}_{\mathrm{m}}$ and $\mathrm{V}_{\text {max }}$ values were estimated from the Michaelis-Mentem equation with the non-linear regression data analysis program Enzifitter (Leatherbarrow, 1999). All experiments were carried out in triplicate, with a standard deviation less than $10 \%$.

\section{Statistical Analysis}

Statistical analyses were performed with the Statistica 8.0 software. Data were submitted to factorial ANOVA and Fisher post hoc tests with significance level of $p<0.05$.

\section{Results}

\section{Partial purification of CMCase}

The crude extract obtained following 7 days growth was assayed for CMCase $(0.904 \mathrm{IU} / \mathrm{mL})$, pectinase $(0.845 \mathrm{IU} / \mathrm{mL})$, mannanase $(0.814 \mathrm{IU} / \mathrm{mL})$, xylanase $(0.744 \mathrm{IU} / \mathrm{mL})$ and FPase activities $(0.268 \mathrm{IU} / \mathrm{mL})$. Due to its higher activity, CMCase was chosen as the main target of this research. Crude extract was then subjected to ultrafiltration through a PM-10 ultrafiltration membrane. After this procedure, CMCase activity was only detected in the concentrated fraction, which in turn was subjected to successive chromatographic methods. In the concentrated fraction, a beta-glucosidase activity of $2.37 \mathrm{IU} / \mathrm{mL}$ was detected, while pectinase, mannanase and xylanase activities were $2.08,1.37$ and $1.26 \mathrm{IU} / \mathrm{mL}$, respectively.

The concentrated fraction (CF) was fractionated by gel filtration chromatography on Sephacryl S100 (Figure 1a). The elution profile showed a single CMCase peak (1.06 IU/mL) which was further fractionated by anion-exchange chromatography on a Q Sepharose Fast Flow. The elution profile of the anion exchange chromatography showed two peaks with endoglucanase activity, with the second $(0.70 \mathrm{IU} / \mathrm{mL}$ ) chosen for purification due to its lower protein peak (Figure 1b). The second peak was pooled and loaded onto a DEAE Sepharose Fast Flow chromatography column (Figure 1c). Two peaks containing cellulase activity were observed, with the fractions of the second peak pooled and denominated $\mathrm{Cb}$-Cel for further enzyme characterization. All collected fractions were stored at $4^{\circ} \mathrm{C}$.

The degree of purity obtained by all purification steps was evaluated by SDS-PAGE and zymography (Figure 2). As demonstrated in the zymogram, $\mathrm{Cb}-\mathrm{Cel}$ and an enzyme preparation from the Q Sepharose Fast Flow showed only one band of CMCase activity. Under denaturing conditions, the gel showed a protein band of approximately $48 \mathrm{kDa}$ for the $\mathrm{Cb}-\mathrm{Cel}$ preparation. The results of the partial purification of CMCase are summarized in Table 1. The successive purification of $\mathrm{Cb}-\mathrm{Cel}$ resulted in a seven-fold increase in purity and $19.5 \%$ recovery. Following the final purification step, Cb-Cel showed activities of CMCase $(0.424 \mathrm{IU} / \mathrm{mL})$, xylanase $(0.250$ $\mathrm{IU}) / \mathrm{ml})$, mannanase $(0.145 \mathrm{IU} / \mathrm{ml})$ and pectinase $(0.108 \mathrm{IU} / \mathrm{mL})$.

\section{Enzymatic hydrolysis}

Concentrated and $\mathrm{Cb}$-Cel samples were incubated with cellulose, hemicellulose and lignocellulosic substrates. With the hydrolysis of filter paper by the concentrated fraction, an increase was observed in the amounts of reducing sugars released during the 48 hours of incubation. Moreover, an increase in reducing sugar release was also observed after the hydrolysis of CMC $4 \%$ by $\mathrm{Cb}-\mathrm{Cel}$ (Figure 3).

Given their high recalcitrance, hydrolysis of soybean hulls and sugarcane bagasse was performed over a 10 day period. Sugar concentrations gradually increased during the 10 day hydrolysis, indicating that hydrolysis time period was an important factor for enzyme action. The amount of sugar released following soybean hull degradation was markedly higher than observed 
following sugarcane bagasse hydrolysis, mostly by action of enzymes from the concentrated fraction. After 10 days of hydrolysis, $5.2 \mathrm{mg} / \mathrm{mL}$ of reducing sugars were released from the hydrolysis of soybean hulls and $0.8 \mathrm{mg} / \mathrm{mL}$ from sugarcane bagasse (Figure 4).
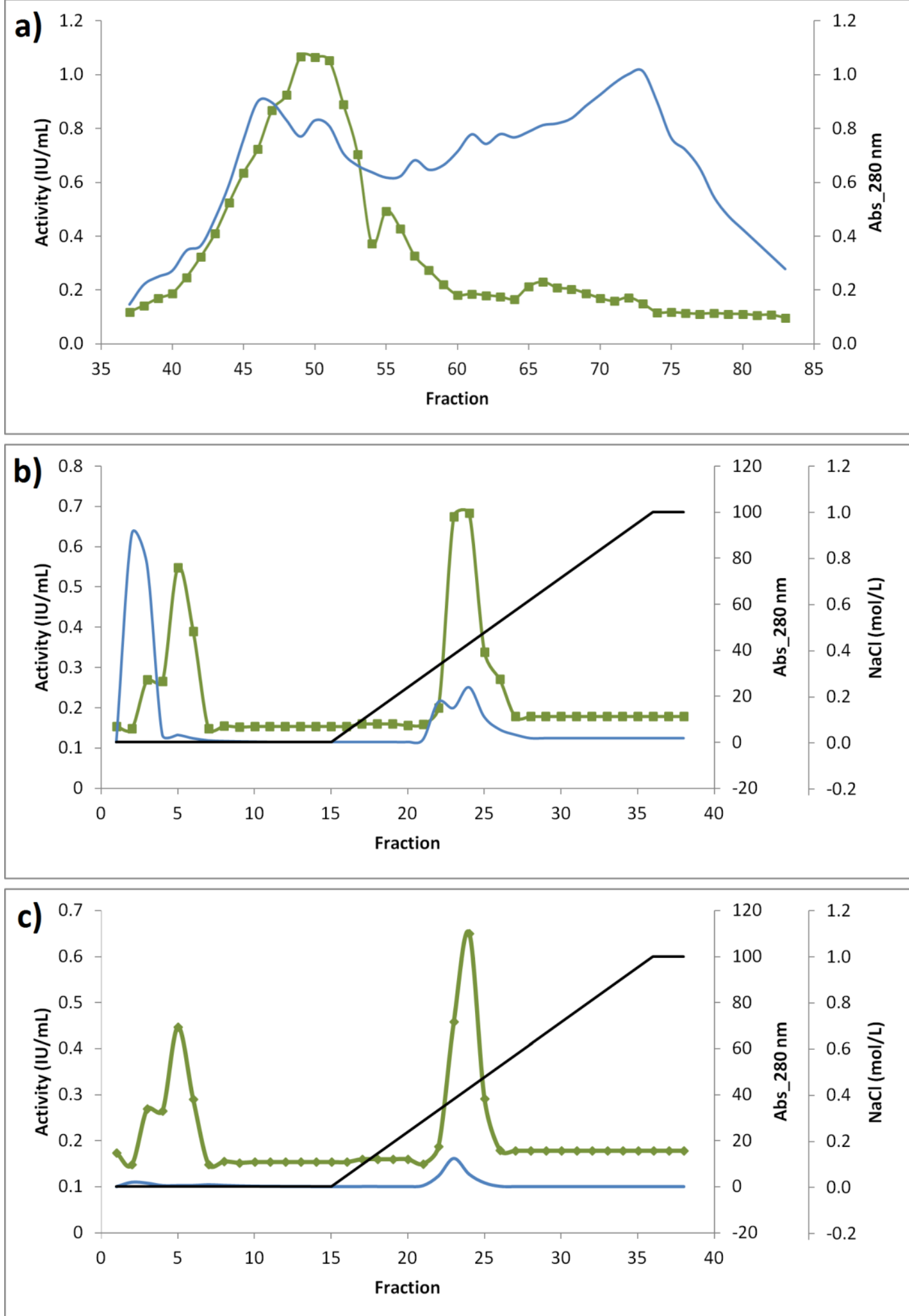

Fig. 1 Purification of Cb-Cel. a) Gel filtration chromatography on Sephacryl S100 column. b) Ionexchange chromatography on HiTrap Q Sepharose Fast Flow column. c) Ion-exchange 
chromatography on HiTrap DEAE Sepharose Fast Flow column. CMCase activity (IU/mL) (匹), Protein $\left(\mathrm{Abs} \_280 \mathrm{~nm}\right)(-)$ and $\mathrm{NaCl}$ gradient $(\mathrm{mol} / \mathrm{L})(-)$.

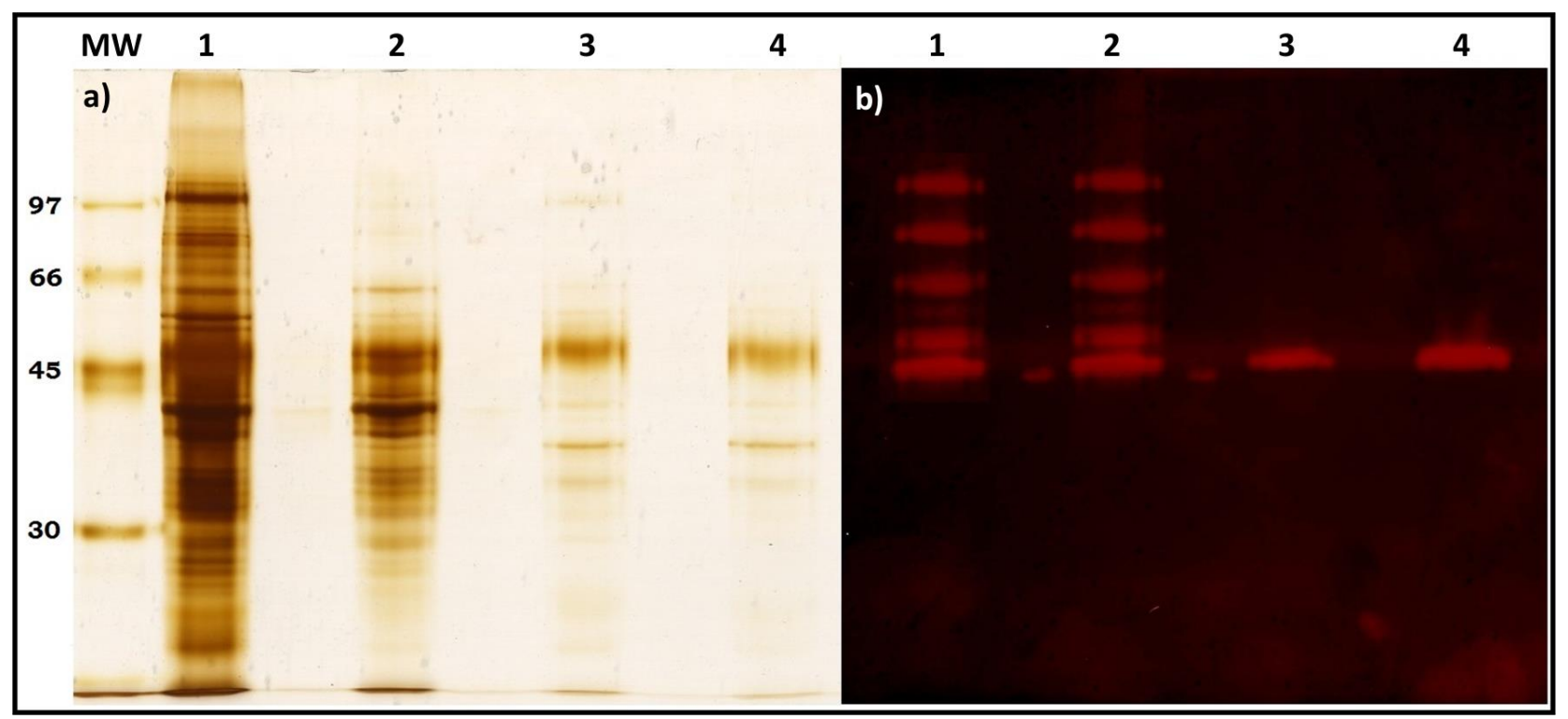

Fig. 2 SDS-PAGE (12\%) of the successive purification steps of $\mathrm{Cb}-\mathrm{Cel}$. The gel was stained with a) silver nitrate or b) $0.1 \%$ congo red. MW (molecular weight marker): phosphorylase b (97 kDa), albumin $(66 \mathrm{kDa})$, ovalbumin $(45 \mathrm{kDa})$ and carbonic anhydrase $(30 \mathrm{kDa})$. Line 1 , concentrated fraction (PM $10 \mathrm{kDa}$ ); line 2, fractions pooled from S100 chromatography; line 3, fractions pooled from Q-FF chromatography; line 4, fractions pooled from DEAE-FF chromatography (Cb-Cel).

Table 1 Summary of partial purification of $\mathrm{Cb}-\mathrm{Cel}$.

\begin{tabular}{|c|c|c|c|c|c|c|c|c|}
\hline Purification Step & $\begin{array}{l}\text { Total } \\
(\mathrm{mg})\end{array}$ & Protein & $\begin{array}{l}\text { Total } \\
\text { (IU) }\end{array}$ & Activity & $\begin{array}{l}\text { Specific } \\
\text { (IU/mg) }\end{array}$ & Activity & $\begin{array}{l}\text { Purification } \\
\text { Fold }\end{array}$ & Yield (\%) \\
\hline Crude Extract & 51.6 & & 258.0 & & 5.0 & & 1.0 & 100.0 \\
\hline $\begin{array}{l}\text { Concentrated } \\
\text { Fraction }\end{array}$ & 11.0 & & 45.0 & & 4.1 & & 0.8 & 17.4 \\
\hline $\begin{array}{l}\text { Gel filtration on } \\
\text { Sephacryl S100 }\end{array}$ & 14.0 & & 122.4 & & 8.7 & & 1.7 & 47.4 \\
\hline $\begin{array}{l}\text { Ion-exchange on } \\
\text { Q-FF }\end{array}$ & 3.8 & & 69.6 & & 18.3 & & 3.7 & 27.0 \\
\hline $\begin{array}{l}\text { Ion-exchange on } \\
\text { DEAE-FF }\end{array}$ & 1.4 & & 50.4 & & 36.0 & & 7.2 & 19.5 \\
\hline
\end{tabular}

Moreover, the amount of glucose gradually increased during saccharification of CMC, filter paper and lignocellulosic substrates. After 48 hours of hydrolysis of filter paper and CMC $4 \%$ by the concentrated fraction, 3.96 and $1.50 \mathrm{mg} / \mathrm{mL}$ of glucose were released, respectively. In the case of hydrolysis of soybean hulls by the concentrated fraction, $2.36 \mathrm{mg} / \mathrm{mL}$ of glucose was released after 240 hours of hydrolysis. Cb-Cel released lower amounts of glucose in all hydrolysis evaluations (data not shown).

The products of hydrolysis of substrates by the concentrated and $\mathrm{Cb}-\mathrm{Cel}$ were identified by HPAEC-PAD, with results summarized in Table 2. Glucose was released from the hydrolysis of 1 and 4\% CMC, filter paper and soybean hulls. All manooligosaccharides were observed following hydrolysis of mannose. A xylooligomers range of X1-X5 was obtained after xylan hydrolysis. 

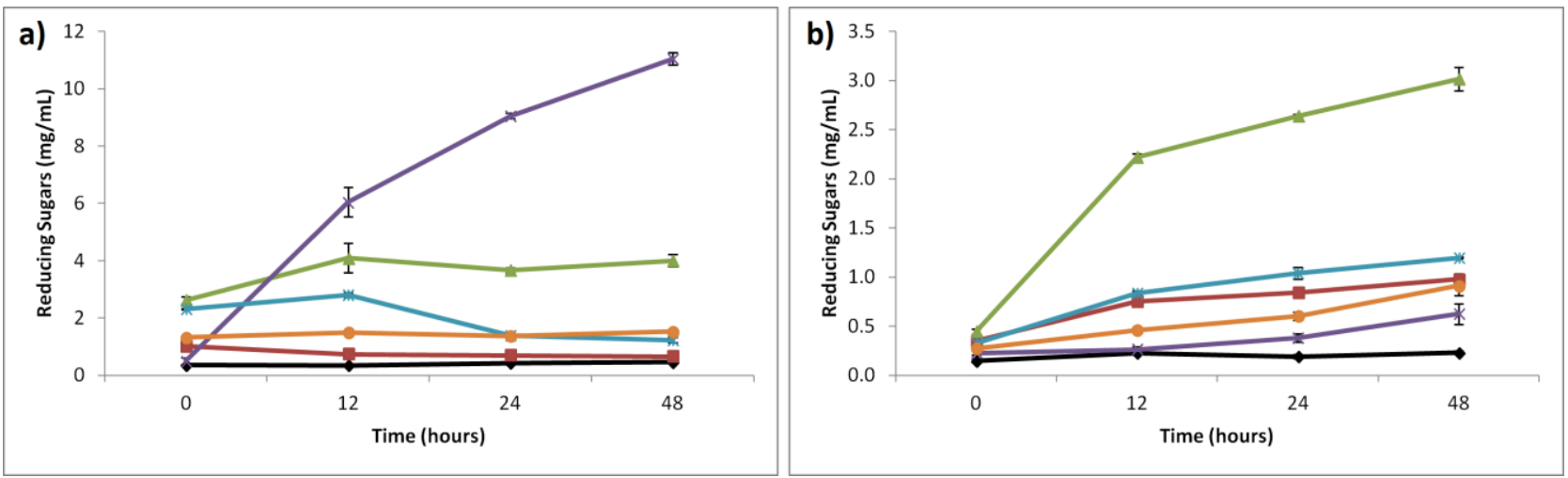

Fig. 3 DNS method-based quantification of total reducing sugars following hydrolysis of $1 \%$ avicel $(\diamond), 1 \%(\mathbf{\square})$ and 4\% ( $\mathbf{\Delta})$ carboxymethylcellulose (CMC), filter paper $(\mathbf{x}), 1 \%$ mannan $(\mathbf{x})$ and $1 \%$ xylan $(\bullet)$ by a) concentrated fraction and b) $\mathrm{Cb}-\mathrm{Cel}$
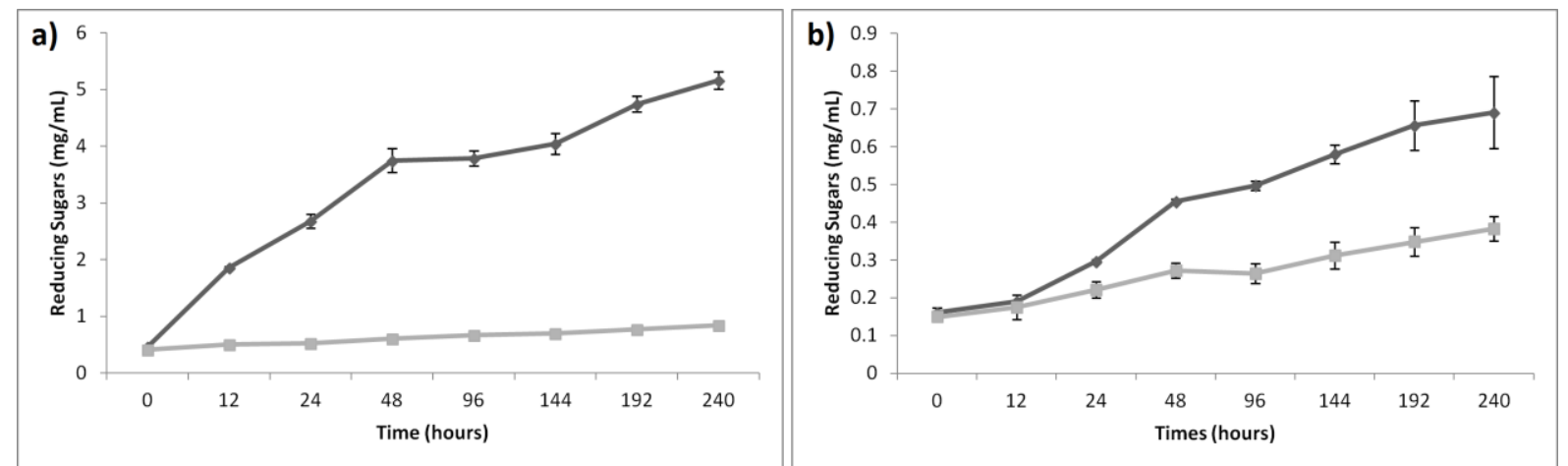

Fig. 4 DNS method-based quantification of total reducing sugars following hydrolysis of $1 \%$ soybean hulls ( $\bullet$ ) and $1 \%$ sugarcane bagasse $(\mathbf{a})$ by a) concentrated fraction and b) $\mathrm{Cb}$-Cel

Table 2 HPAEC-PAD-based identification of the hydrolysis products released by concentrated fraction and $\mathrm{Cb}-\mathrm{Cel}$.

\begin{tabular}{lll}
\hline & Products of hydrolysis \\
\cline { 2 - 3 } Substrate & Concentrated Fraction & Cb-Cel \\
\hline CMC 1\% & G1, G5 & G1, G2 \\
CMC 4\% & G1, G5, G6 & G1 \\
Filter Paper & G1, G5 & G1 \\
Mannan 1\% & M1, M2, M3, M4, M5 & M1, M2, M3, M4, M5, M6 \\
Xylan 1\% & X1, X2, X3, X4, X5 & X2, X3 \\
Soybean Hulls 1\% & G1, G4, G5, G6, M2, M4, X2 & G1, G5, M1, X2, X5 \\
Sugarcane Bagasse 1\% & G6, M1, X1, X4 & G6, X2 \\
\hline
\end{tabular}

G1: glucose, G2: cellobiose, G5: cellopentaose, G6: cellohexaose, M1: mannose, M2: mannobiose, M3: mannotriose, M4: mannotetraose, M5: mannopentaose, M6: :mannohexaose, X1: xylose, X2: xylobiose, X3: xylotriose, X4: xylotetraose, X5: xylopentaose. 
The enzymatic hydrolysis of soybean hulls by the concentrated fraction yielded predominantly cellohexaose and cellopentaose, which were released between $12 \mathrm{~h}$ and $48 \mathrm{~h}$, a period during which a low amount of glucose was also released (Figure 5). Moreover, mannotetraose (during the interval of 12 and 48h) and mannobiose (during the interval of 96 and 240h) were released in lower amounts $(<0.2 \mu \mathrm{g} / \mathrm{mL})$ (data not shown). Following the hydrolysis by $\mathrm{Cb}-\mathrm{Cel}$, xylobiose and mannose were the main reducing sugars detected between 12 and 48h. Comparatively, smaller quantities of saccharides were obtained after hydrolysis of soybean hulls by $\mathrm{Cb}-\mathrm{Cel}$.
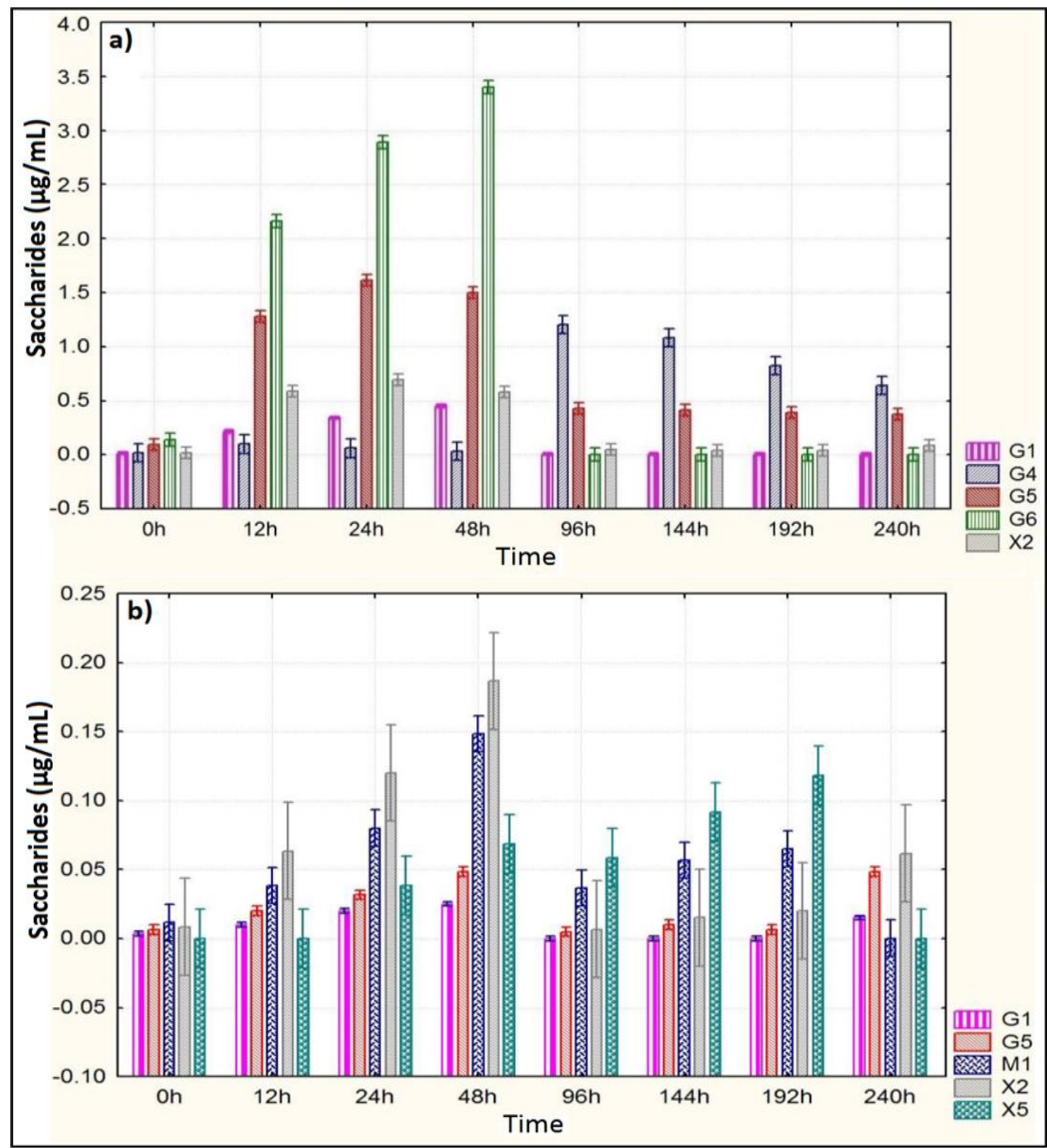

Fig. 5 Identification and quantification of the main saccharides released from $1 \%$ soybean hulls following hydrolysis over time by enzymes from a) concentrated fraction and b) Cb-Cel

As presented previously, the quantification of total reducing sugars by the DNS method showed that enzymatic hydrolysis of sugarcane bagasse released lower amounts of reducing sugars compared to hydrolysis of soybean hulls. This result was corroborated by the identification and quantification of hydrolysis products by HPAEC-PAD. In this case, the degradation of sugarcane 
bagasse released only cellohexaose, mannose, xylose and xylotetraose (concentrated fraction), with cellohexaose and xylobiose $(\mathrm{Cb}-\mathrm{Cel})$ in low quantities $(<0.3 \mu \mathrm{g} / \mathrm{mL})$ (data not shown).

\section{Enzymatic characterization}

\section{Effect of temperature, $\mathrm{pH}$ and thermostability on CMCase activity}

The effect of temperature and $\mathrm{pH}$ on CMCase activity from the concentrated fraction and $\mathrm{Cb}-\mathrm{Cel}$ is shown in figure 6 . The highest activity was obtained at 60 and $70^{\circ} \mathrm{C}$, and $\mathrm{pH} 4.5$ and 5.0, for the concentrated fraction and $\mathrm{Cb}$-Cel, respectively. $\mathrm{Cb}-\mathrm{Cel}$ was active over a broad range of temperatures and $\mathrm{pH}$, retaining at least $60 \%$ of its activity between 40 and $80^{\circ} \mathrm{C}$ and $\mathrm{pH} 4.0$ to 7.5. The concentrated fraction retained at least $68 \%$ of its activity at temperatures from 30 to $70^{\circ} \mathrm{C}$, with this enzymatic fraction also active over a wide range of $\mathrm{pH}$ values, retaining at least $60 \%$ of relative activity between $\mathrm{pH} 3.5$ to 9.0 .
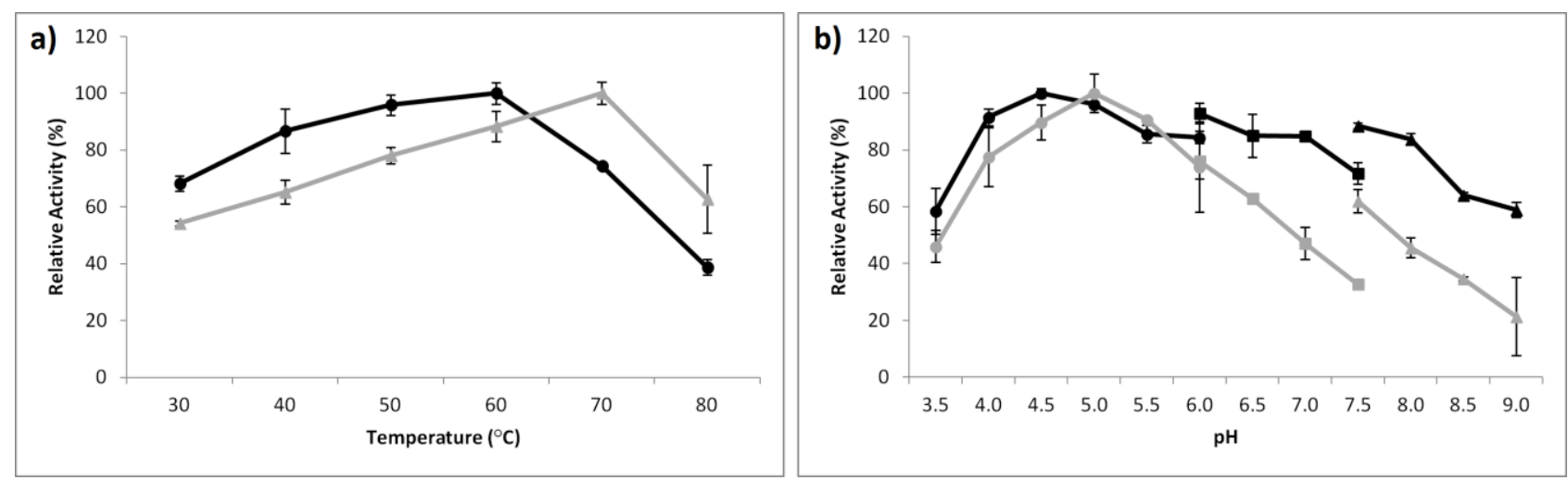

Fig. 6 Effect of temperature (a) and $\mathrm{pH}$ (b) on CMCase activity from concentrated fraction (black line) and $\mathrm{Cb}-\mathrm{Cel}$ (gray line). Buffers: sodium acetate ( $\mathrm{pH} 3.5-6.0)$, sodium phosphate ( $\mathrm{pH}$ 6.0-7.5) and Tris- $\mathrm{HCl}(\mathrm{pH} 7.5-9.0)$.

$\mathrm{Cb}$-cel showed elevated thermostability at 40 and $50^{\circ} \mathrm{C}$. After 30 days incubation, $97 \%$ of its initial activity was maintained at $40^{\circ} \mathrm{C}$. At $50^{\circ} \mathrm{C}$, this enzyme also maintained $67 \%$ of its relative activity for 25 days (Figure 7). At $60^{\circ} \mathrm{C}$, the $\mathrm{Cb}$-Cel half-life was approximately 3 hours.

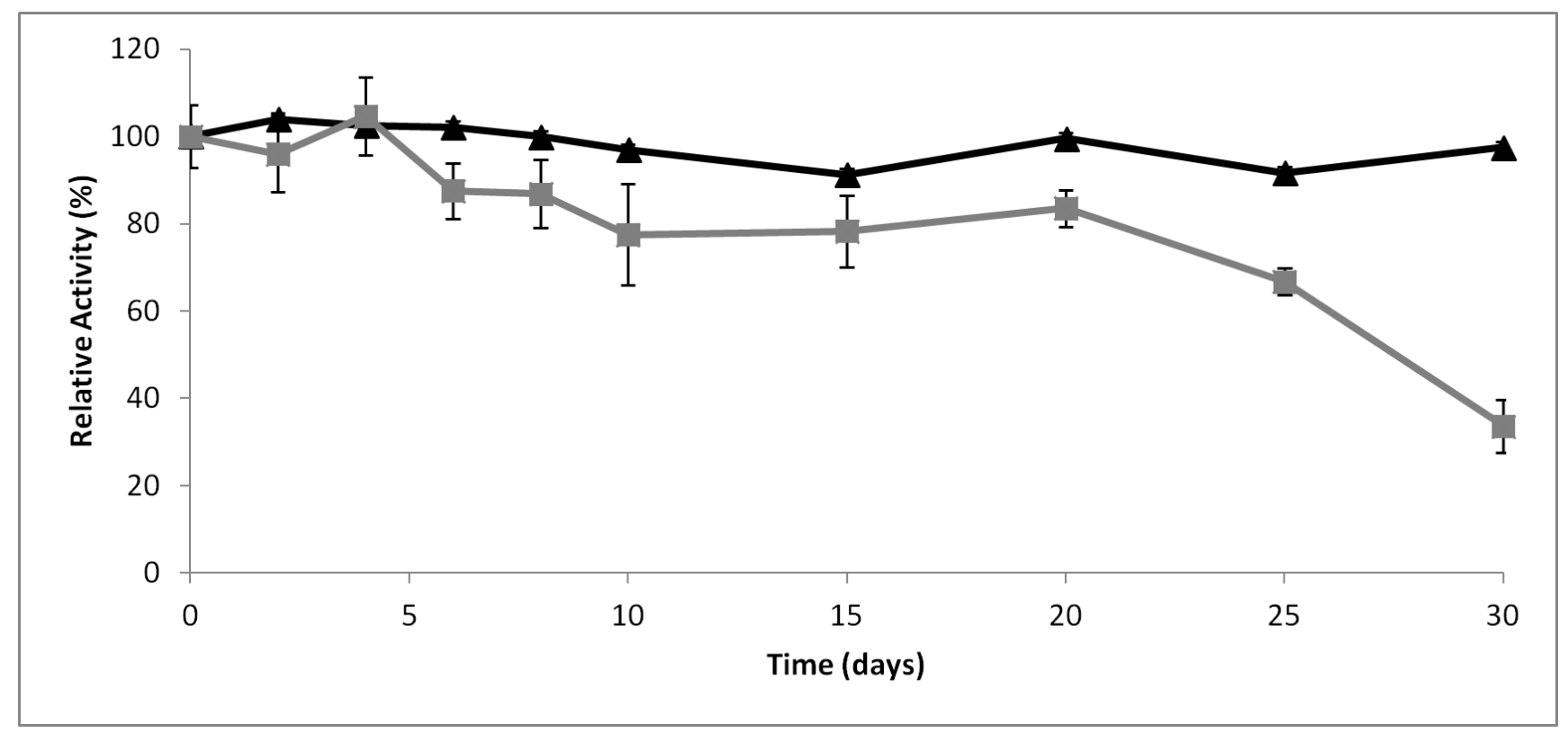


Fig. 7 Thermostability of $\mathrm{Cb}-\mathrm{Cel}$ at $40^{\circ} \mathrm{C}(\boldsymbol{\Delta})$ and $50^{\circ} \mathrm{C}(\mathbf{\square})$.

\section{Effect of phenolic compounds on CMCase activity}

The inhibitory and deactivator effects of oligomeric (tannic acid) and monomeric phenolic compounds (vanillin, 4-hydroxybenzoic, ferulic, $\rho$-coumaric and cinnamic acids) on the concentrated fraction and $\mathrm{Cb}-\mathrm{Cel}$ activities were evaluated. According to Ximenes et al. (2011), inhibition occurs immediately after the incubation of the enzyme with the phenols, while deactivation is related to the incubation time. Figure 8 shows the effect of such compounds with the concentrated fraction and $\mathrm{Cb}-\mathrm{Cel}$. The concentration of phenolic compounds at $1 \mathrm{mg} / \mathrm{mL}$ did not interfere with the DNS assay, in contrast to higher concentrations (5 and $10 \mathrm{mg} / \mathrm{mL}$ ) of such compounds which were found to interfere with the assay (data not shown). Overall, $\mathrm{Cb}-\mathrm{Cel}$ and the concentrated fraction were resistant to phenolic compounds. CMCase activity of $\mathrm{Cb}-\mathrm{Cel}$ showed an increase of $25 \%$ and $18 \%$ at zero time after incubation with ferulic and tannic acids, respectively.
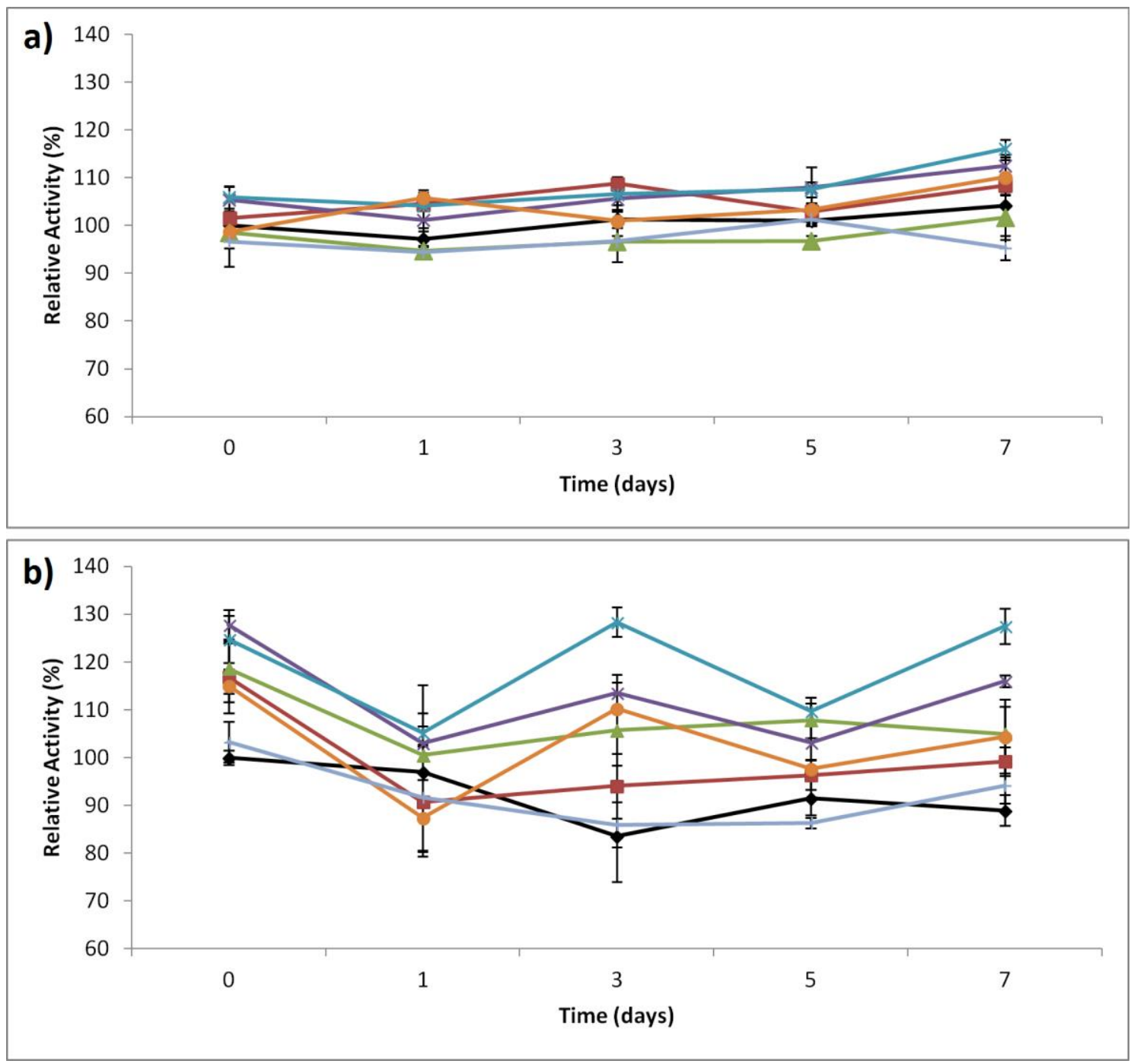

Fig. 8 Inhibitory and deactivator effects of phenols $(1 \mathrm{mg} / \mathrm{mL})$ on CMCase activity from a) concentrated fraction and b) $\mathrm{Cb}-\mathrm{Cel}$. Control $(\boldsymbol{\vee})$, vanillin $(\boldsymbol{\bullet})$, tannic acid $(\boldsymbol{\Delta})$, 4-hydroxybenzoic $\operatorname{acid}(\mathbf{x})$, ferulic acid $(\mathbf{x}), \rho$-coumaric acid $(\bullet)$ and cinnamic acid $(+)$.

\section{Effect of metal ions and EDTA on CMCase activity and determination of kinetic parameters}

The effect of metal ions and EDTA on Cb-Cel activity at concentrations of 1 and $10 \mathrm{mM}$ was evaluated (Table 3). $\mathrm{Fe}^{3+}$ and $\mathrm{Fe}^{2+}$ at $10 \mathrm{mM}$ resulted in a severe inhibition (more than 90\%) of 
$\mathrm{Cb}$-Cel activity. $\mathrm{CuSO}_{4}$ and $\mathrm{ZnSO}_{4}(10 \mathrm{mM})$ decreased the enzyme activity by approximately $70 \%$ and $40 \%$, respectively. By contrast, $\mathrm{Co}^{2+}$ at $10 \mathrm{mM}$ had an activator effect on CMCase activity from the concentrated fraction and $\mathrm{Cb}-\mathrm{Cel}$ of 16.4 and 24.6\%, respectively. Moreover, the chelating agent EDTA showed no inhibitory or activation effect on CMCase activity from the samples evaluated. The rate dependence of the endoglucanase reaction on CMC followed MichaelisMenten. Non-linear regression data analysis of $\mathrm{Cb}-\mathrm{Cel}$ acting on CMC showed $\mathrm{Km}$ and $\mathrm{Vmax}$ values of $15.81 \pm 1.65 \mathrm{mg} / \mathrm{mL}$ and $0.59 \pm 0.03 \mathrm{IU} / \mathrm{mL}$, respectively.

Table 3 Effect of metal ions and EDTA at $1 \mathrm{mM}$ and $10 \mathrm{mM}$ on CMCase activity from the concentrated fraction $(\mathrm{CF})$ and $\mathrm{Cb}-\mathrm{Cel}$

\begin{tabular}{|c|c|c|c|c|}
\hline \multicolumn{5}{|c|}{ Relative Activity (\%) } \\
\hline & \multicolumn{2}{|c|}{$1 \mathrm{mM}$} & \multicolumn{2}{|c|}{$10 \mathrm{mM}$} \\
\hline & $\mathrm{CF}$ & $\mathrm{Cb}-\mathrm{Cel}$ & $\mathrm{CF}$ & $\mathrm{Cb}-\mathrm{Cel}$ \\
\hline Control & $100.0 \pm 1.08$ & $100.0 \pm 0.10$ & $100.0 \pm 3.13$ & $100.0 \pm 3.32$ \\
\hline $\mathrm{CaCl}_{2}$ & $96.7 \pm 2.75$ & $96.8 \pm 1.42$ & $107.5 \pm 4.66$ & $90.1 \pm 2.94$ \\
\hline $\mathrm{CoCl}_{2}$ & $114.4 \pm 0.64$ & $116.4 \pm 2.11$ & $116.4 \pm 4.71$ & $124.6 \pm 2.94$ \\
\hline $\mathrm{CuCl}_{2}$ & $94.6 \pm 4.95$ & $66.0 \pm 5.08$ & $90.6 \pm 3.34$ & $86.8 \pm 4.54$ \\
\hline $\mathrm{CuSO}_{4}$ & $87.9 \pm 0.86$ & $67.0 \pm 1.47$ & $88.9 \pm 2.49$ & $30.1 \pm 4.98$ \\
\hline $\mathrm{FeCl}_{3}$ & $104.9 \pm 5.25$ & $47.6 \pm 1.62$ & $90.5 \pm 2.37$ & $0.0 \pm 0.00$ \\
\hline $\mathrm{FeSO}_{4}$ & $102.4 \pm 0.82$ & $75.6 \pm 1.05$ & $94.8 \pm 2.91$ & $6.1 \pm 7.23$ \\
\hline $\mathrm{KCl}$ & $100.0 \pm 1.24$ & $95.0 \pm 1.79$ & $91.1 \pm 2.01$ & $97.1 \pm 6.19$ \\
\hline $\mathrm{MgCl}_{2}$ & $121.7 \pm 0.82$ & $98.0 \pm 6.49$ & $98.3 \pm 0.36$ & $107.8 \pm 1.78$ \\
\hline $\mathrm{MgSO}_{4}$ & $96.6 \pm 1.55$ & $96.0 \pm 4.87$ & $98.5 \pm 1.32$ & $98.9 \pm 2.74$ \\
\hline $\mathrm{NaCl}$ & $106.3 \pm 1.14$ & $96.2 \pm 3.64$ & $106.7 \pm 3.88$ & $90.4 \pm 3.39$ \\
\hline $\mathrm{ZnCl}_{2}$ & $107.9 \pm 0.40$ & $99.7 \pm 2.20$ & $107.6 \pm 0.53$ & $63.1 \pm 2.36$ \\
\hline $\mathrm{ZnSO}_{4}$ & $102.7 \pm 2.14$ & $72.9 \pm 3.86$ & $106.1 \pm 0.96$ & $58.9 \pm 5.79$ \\
\hline EDTA & $98.5 \pm 0.66$ & $102.6 \pm 3.48$ & $99.7 \pm 2.66$ & $102.3 \pm 2.84$ \\
\hline
\end{tabular}

\section{Discussion}

Agro-industrial wastes represent an important alternative source of carbon for microbial growth and subsequent production of industrial enzymes. For example, cellulases are known to be synthesized by microorganisms during growth on wheat bran as cellulosic material (Rawat \& Tewari 2012). Within this context, a variety of lignocellulosic substrates were evaluated as carbon sources for $C$. byssicola growth and cellulase production. In this study, C. byssicola secreted multiple cellulases, as demonstrated by zymogram analysis, wherein five bands with CMCase activity were observed. As with $C$. byssicola, many other microorganisms, such as Trichoderma reesei (Miettinen-Oinonen 2004), Myceliophthora sp. (Badhan et al. 2007) and Aspergillus fumigatus (Lima et al. 2009), are also known to produce cellulolytic enzymes in multiple isoforms, which have distinct biochemical properties, molecular weight and substrate specificity. This multiplicity of isoforms is an interesting feature, given that many enzymes are known to act synergistically to hydrolyze substrates more efficiently.

Analysis of the hydrolysis of all the substrates evaluated showed greater amounts of reducing sugars released by the concentrated fraction when compared to $\mathrm{Cb}$-Cel. Taking into account that CMCase activity was not detected in the ultrafiltrate fraction, during purification of $\mathrm{Cb}$-Cel at least five CMCase activities were present. Since these enzymes act synergistically for the complete hydrolysis of cellulose, the yield and fold values were probably underestimated.

As shown previously, soybean hull hydrolysis by the concentrated fraction and $\mathrm{Cb}-\mathrm{Cel}$ released markedly higher amounts of reducing sugar than sugarcane bagasse degradation. Given that the fungus $C$. byssicola was grown in medium supplemented with soybean hulls as carbon source, it is likely that the enzymes secreted during microbial growth are more active on this substrate. A hypothesis for this fact is that differences in the structure of the cell wall of soybean hulls and sugarcane bagasse leads the fungus to release enzymes that are more suitable to the deconstruction of the cell wall of this lignocellulosic biomass employed for its growth. Juhász et 
al. (2005) also observed that the enzymatic hydrolysis of willow and corn stover was more efficient when enzymes were produced by $T$. reeseei following grown in liquid medium containing the respective substrate as carbon source.

Identification and quantification by HPAEC-PAD showed that hydrolysis products of CMC and filter paper by secreted enzymes from $C$. byssicola were mainly glucose, cellopentaose and cellohexaose. The ability to hydrolyze CMC suggests that the semi-purified enzymes obtained in this study are endoglucanases, since cellobiohydrolases are not able to degrade this substrate due to the carboxymethyl side groups, which prevent the cellulose chain from entering the narrow tunnel leading to the active site of the cellobiohydrolases (Jørgensen et al. 2003). In addition, HPLC analysis showed a major liberation of cellooligomers with greater polymerization degree instead of glucose, corroborating the classification of these enzymes as endoglucanases. Given that endoglucanases hydrolyze glycosidic bonds at different positions of the cellulose chain, hydrolysis products vary considerably. For example, enzymatic hydrolysis of CMC by a purified CMCase from Daldinia eschscholzii generated cellobiose, cellotriose, cellotetraose and lower amounts of glucose (Karnchanatat et al. 2008). Furthermore, Liu et al. (2011) performed enzymatic hydrolysis of cellooligosacharides (G2, G3, G4 and G5) and CMC with two purified CMCases from Aspergillus fumigatus, named Egl2 and Egl3. They observed that Egl2 hydrolyzed cellotetraose and cellopentaose, while Egl3 hydrolyzed cellotriose, cellotetraose and cellopentaose. In CMC degradation, Egl2 released cellobiose, cellotriose and cellotetraose, while Egl3 generated glucose and cellobiose.

With regard to the characterization of $\mathrm{Cb}-\mathrm{Cel}$, activity was observed over a wide temperature and $\mathrm{pH}$ range, indicating suitability for application in industrial processes. CMCases commonly present optimum temperature around $60-70^{\circ} \mathrm{C}$. Previous studies have reported highest activity at $60^{\circ} \mathrm{C}$, such as EGa from Penicillium occitanis (Chaabouni et al. 2005) and EG3 from Aspergillus fumigatus (Liu et al. 2011). Similarly, numerous studies have described CMCases more active at $70^{\circ} \mathrm{C}$, for example in Penicillium purpurogenum KJS506 (Lee et al. 2010), Thermoascus aurantiacus (Parry et al. 2002, Dave et al. 2014), Daldinia eschscholzii (Karnchanatat et al. 2008) and Penicillium brasilianum (Krogh et al. 2009). Optimum activity at $\mathrm{pH} 5.0$ was reported for CMCases from Thermomonospora sp. (George et al. 2001), Streptomyces drozdowiczii (Lima et al. 2005), Aspergillus aculeatus (Naika et al. 2007), Penicillium purpurogenum (Lee et al. 2010) and Aspergillus fumigatus (Liu et al. 2011).

Our results indicated an elevated thermostability of $\mathrm{Cb}-\mathrm{Cel}$ at 40 and $50^{\circ} \mathrm{C} . \mathrm{Cb}-\mathrm{Cel}$ presented higher thermostability than several other endoglucanases, such as an endoglucanase from Aspergillus terreus that lost $50 \%$ of its activity in less than 6 hours of incubation at $50^{\circ} \mathrm{C}$ (Narra et al. 2014). Cb-cel was also more thermostable than the recombinant endoglucanases ApCel5A (from Aureobasidium pullulans), GtCel12A (from Gloeophyllum trabeum) and StCel5A (from the thermophilic fungus Sporotrichum thermophile), which all presented a half-life of 2 hours at $45^{\circ} \mathrm{C}$, $50^{\circ} \mathrm{C}$ and $55^{\circ} \mathrm{C}$, respectively (Tambor et al. 2012). Lee et al. (2010) reported that CMCase from Penicillium purpurogenum showed a half-life of $72 \mathrm{~h}, 48 \mathrm{~h}, 7 \mathrm{~h}$ and $2 \mathrm{~h}$ at $40,50,60$ and $70^{\circ} \mathrm{C}$, respectively. Since $\mathrm{Cb}-\mathrm{Cel}$ was partially purified, it is likely there are stabilizing factors enhancing its thermostability. Thus, $\mathrm{Cb}-\mathrm{Cel}$ shows potential for future biotechnological applications.

Phenolic compounds, which result from the degradation of lignin, may be inhibitory to enzymes and/or fermentative organisms. As such, the employment of enzymes resistant to phenols is crucial for efficient biomass hydrolysis (Duarte el al. 2012). Cb-Cel was resistant to inhibition and deactivation by the evaluated phenolic compounds. Our results showed that tannic acid $(1 \mathrm{mg} / \mathrm{mL}$ ) increased $\mathrm{Cb}$-Cel activity at the beginning of the assay (time zero). On the other hand, there are numerous reports in the literature reporting inhibitory effects of phenols on cellulase activities. For instance, Ximenes et al. (2011) investigated inhibitory and deactivator effects of tannic acid on cellulases from Trichoderma reesei. Tannic acid at $2 \mathrm{mg} / \mathrm{mL}$ inhibited CMCase and FPase activities by approximately $25 \%$ and $60 \%$, respectively. After $24 \mathrm{~h}$ incubation, tannic acid at $5 \mathrm{mg} / \mathrm{mL}$ presented a deactivator effect and decreased CMCase and FPase activities by $80 \%$ and $60 \%$, respectively. Other studies have reported that vanillin, syringaldehyde, trans-cinnamic acid 
and hydroxybenzoic acid inhibit cellulose hydrolysis in wet cake by endo- and exo-cellulases (Ximenes et al. 2010). The effects of phenolic compounds are observed not only in terms of enzymatic activity but also in the production of enzymes by microorganisms. Vohra et al. (1980) observed that vanillin at $0.5 \mathrm{mg} / \mathrm{mL}$ inhibited the production of CMCase, avicelase and $\beta$ glucosidase from $T$. reesei by $78 \%, 100 \%$ and $100 \%$, respectively, and also inhibited fungal growth by $94 \%$. Ferulic acid inhibited the production of the same enzymes by $75 \%, 86 \%$ and $100 \%$, respectively, but had little effect on microbial growth. Berlin et al. (2006) demonstrated that seven cellulase preparations were inhibited by a dissolved lignin preparation. Similarly, phenolic derived from pretreated sugarcane bagasse deactivated cellulolytic enzymes (Michelin et al. 2015). By contrast, there are also reports of increased hemicellulase activities in the presence of phenolic compounds, such as observed with a commercial xylanase preparation, with activity enhanced by $50 \%$ after the addition of vanillic acid at low concentrations $(0.05 \%)$, and hydrolysis of xylan improved by the addition of vanillin and guaiacol (Kaya et al. 2000). Similarly, another xylanase, named XylT2, showed an improvement in its activity by approximately $50 \%$ in the presence of vanillin, ferulic acid and 4-hydroxybenzoic acid (Moreira et al. 2013). Phenolic compounds can have a wide variety of effects on enzymes activity, increasing enzymatic activity under certain conditions. As such, enzyme activities and the presence of lignin degradation products are not likely to be correlated in a simple manner (Kaya et al. 2000). In this way, as Cb-cel displayed resistance to several phenolic compounds, it shows potential for use in industrial processes.

The inhibition or activation of cellulases by selected chemicals is a useful approach for the study of active site structure and its mechanism of action. Among the divalent metal ions, most often $\mathrm{Cu}^{2+}$ and $\mathrm{Fe}^{2+}$ are found to exert strong inhibition on cellulolytic enzymes, such as cellobiohydrolases, endoglucanases and $\beta$-glucosidases (Tejirian \& Xu 2010). The data reported here is corroborated by studies performed by Li et al. (2006) and Karnchanatat et al. (2008), wherein endoglucanase activity decreased in the presence of both $\mathrm{Cu}^{2+}$ and $\mathrm{Fe}^{2+}$. Elvan et al. (2010) and Xiang et al. (2014) also observed inhibitory effects of $\mathrm{Cu}^{2+}$ on CMCase. The inhibitory effect of these ions can be ascribed to a detrimental interaction with cellulases, which can cause conformational changes or replacement of native metal cofactors (Tejirian \& Xu 2010). Moreover, the chelating agent EDTA showed no inhibitory effect on CMCase activity from $C$. byssicola, indicating that the activity of this enzyme does not depend on the presence of metal ions. In comparison with $\mathrm{Km}$ value of an endoglucanase from Penicillium funiculosum (Castro et al. 2010), $\mathrm{Cb}-\mathrm{Cel}$ showed lower affinity for CMC.

In conclusion, both the concentrated fraction and $\mathrm{Cb}$-Cel from $C$. byssicola were able to hydrolyze multiples substrates, releasing both monomers and oligomers. Greater amounts of reducing sugars were detected from the hydrolysis of soybean hulls than from sugarcane bagasse. This is probably a result of the fact that soybean hulls were used as initial carbon source for fungal growth, with the release of enzymes more suitable to the degradation of this substrate. $\mathrm{Cb}-\mathrm{Cel}$ showed activity over a broad range of $\mathrm{pHs}$ and temperatures, with elevated thermostability. Additionally, $\mathrm{Cb}-\mathrm{Cel}$ displayed resistance to several phenolic compounds which is of relevance for industrial biofuel production, given that such compounds are formed during lignocellulosic biomass pre-treatment.

\section{Acknowledgments}

The authors acknowledge the receipt of financial support from the Brazilian National Council for Scientific and Technological Development (CNPq), Coordination for the Improvement of Higher Education Personnel (CAPES), The Foundation for Research Support of the Federal District (FAPDF) and National Institute for Science and Technology of Bioethanol.

\section{References}


Altschul SF, Madden TL, Schaffer AA, Zhang J, Zhang Z, Miller W, Lipman DJ. 1997 - Gapped BLAST and PSI-BLAST: a new generation of protein database search programs. Nucleic Acids Research 25, 3389-3402.

Alvindia DG \& Natsuaki KT. 2008 - Evaluation of fungal epiphytes isolated from banana fruit surfaces for biocontrol of banana crown rot disease. Crop Protection 27, 1200-1207.

Badhan AK, Chadha BS, Kaur J, Saini HS, Bhat MK. 2007 - Production of multiple xylanolytic and cellulolytic enzymes by thermophilic fungus Myceliophthora sp. IMI 387099. Bioresource Technology 98, 504-510.

Berlin A, Balakshin M, Gilkes N, Kadla J, Maximenko V, Kubo S, Saddler J. 2006 - Inhibition of cellulase, xylanase and $\beta$-glucosidase activities by softwood lignin preparations. Journal of Biotechnology 125(2), 198-209.

Bhat MK. 2000 - Cellulases and related enzymes in biotechnology. Biotechnology Advances 18, 355-383.

Bischoff KM, Shi L, Kennelly PJ. 1998 - The detection of enzyme activity following sodium dodecyl sulfate-polyacrylamide gel electrophoresis. Analytical biochemistry 260, 1-17.

Blum H, Beier H, Gross HJ. 1987 - Improved silver staining of plant-proteins, RNA and DNA in polyacrylamide gels. Electrophoresis 8, 93-99.

Bradford MM. 1976 - A rapid and sensitive method for the quantitation of microgram quantities of protein utilizing the principle of protein-dye binding. Analytical biochemistry 72, 248-254.

Castro AM., Carvalho MLA, Leite SGF, Pereira N. 2010 - Cellulases from Penicillium funiculosum: production, properties and application to cellulose hydrolysis. Journal of Industrial Microbiology \& Biotechnology 37, 151-158.

Chaabouni SE, Mechichi T, Limam F, Marzouki N. 2005 - Purification and Characterization of Two Low Molecular Weight Endoglucanases Produced by Penicillium occitanis Mutant Pol 6. Applied Biochemistry and Biotechnology 125, 99-112.

Dave BR, Sudhir AP, Subramanian RB. 2014 - Purification and properties of an endoglucanase from Thermoascus aurantiacus. Biotechnology Reports 55, 1-6.

Doherty WOS, Mousavioun P, Fellows CM. 2011 - Value-adding to cellulosic ethanol: Lignin polymers. Industrial Crops and Products 33, 259-276.

Duarte GC, Moreira LRS, Jaramillo PMD, Filho EXF. 2012 - Biomass-Derived Inhibitors of Holocellulases. Bioenergy Research 5(3), 768-777.

Elvan H, Ertunga NS, Yildirim M, Colak A. 2010 - Partial purification and characterization of endoglucanase from an edible mushroom, Lepista flaccida. Food Chemistry 123, 291-295.

Evans HC, Holmes KA, Thomas SE. 2003 - Endophytes and mycoparasites associated with an indigenous forest tree, Theobroma gileri, in Ecuador and a preliminary assessment of their potential as biocontrol agents of cocoa diseases. Mycological Progress 2(2), 149-160.

García RAM, Hoopen GM, Kas DCJ, Garita VAS, Krauss U. 2003 - Evaluation of mycoparasites as biocontrol agents of Rosellinia root rot in cocoa. Biological Control 27, 210-227.

George SP, Ahmad A, Rao MB. 2001 - Studies on carboxymethyl cellulase produced by an alkalothermophilic actinomycete. Bioresource Technology 77, 171-175.

Glass NL \& Donaldson GC. 1995 - Development of primer sets designed for use with the PCR to amplify conserved genes from filamentous ascomycetes. Applied Environmental Microbiology 61(4), 1323-1330.

Gnanasambandan R \& Proctor A. 1999 - Preparation of soy hull pectin. Food Chemistry 65, 461467.

Hoopen GM, Rees R, Aisa P, Stirrup T, Krauss U. 2003 - Population dynamics of epiphytic mycoparasites of the genera Clonostachys and Fusarium for the biocontrol of black pod (Phytophthora palmivora) and moniliasis (Moniliophthora roreri) on cocoa (Theobroma cacao). Mycological Research 107(5), 587-596.

Jørgensen H, Eriksson T, Börjesson J, Tjerneld F, Olsson L. 2003 - Purification and characterization of five cellulases and one xylanase from Penicillium brasilianum IBT 20888. Enzyme and Microbial Technology 32, 851-861. 
Juhász T, Szengyel Z, Réczey K, Siika-Aho M, Viikari L. 2005 - Characterization of cellulases and hemicellulases produced by Trichoderma reesei on various carbon sources. Process Biochemistry 40, 3519-3525.

Karnchanatat A, Petsom A, Sangvanich P, Piapukiew J, Whalley AJS, Reynolds CD, Gadd GM, Sihanonth P. 2008 - A novel thermostable endoglucanase from the wood-decaying fungus Daldinia eschscholzii (Ehrenb.:Fr.) Rehm. Enzyme and Microbial Technology 42, 404-413.

Kaya F, Heitmann JA, Joyce TW. 2000 - Influence of lignin and its degradation products on enzymatic hydrolysis of xylan. Journal of Biotechnology 80(3), 241-247.

Krauss U, Hoopen GM, Hidalgo E, Martínez A, Stirrup T, Arroyo C, García J, Palacios M. 2006 The effect of cane molasses amendment on biocontrol of frosty pod rot (Moniliophthora roreri) and black pod (Phytophthora spp.) of cocoa (Theobroma cacao) in Panama. Biological Control 39, 232-239.

Krogh KBRM, Kastberg H, Jørgensen CI, Berlin A, Harris PV, Olsson L. 2009 - Cloning of a GH5 endoglucanase from genus Penicillium and its binding to different lignins. Enzyme and Microbial Technology 44, 359-367.

Laemmli UK. 1970 - Cleavage of Structural Proteins during the Assembly of the Head of Bacteriophage T4. Nature 227, 680-685.

Leatherbarrow, RJ. 1999 - Enzifitter Mannual, a non-linear curve fitting program for windows. Biosoft, London.

Lee K, Jeya M, Joo A, Singh R, Kim I, Lee J. 2010 - Purification and characterization of a thermostable endo- $\beta$-1,4-glucanase from a novel strain of Penicillium purpurogenum. Enzyme and Microbial Technology 46, 206-211.

Li Y, Ding M, Wang J, Xu G, Zhao F. 2006 - A novel thermoacidophilic endoglucanase, Ba-EGA, from a new cellulose-degrading bacterium, Bacillus sp.AC-1. Applied Microbiology and Biotechnology 70, 430-436.

Li Y, Qi B, Wan Y. 2014 - Inhibitory effect of vanillin on cellulase activity in hydrolysis of cellulosic biomass. Bioresource Technology 167, 324-330.

Lima ALG, Nascimento RP, Bon EPS, Coelho RRR. 2005 - Streptomyces drozdowiczii cellulase production using agro-industrial by-products and its potential use in the detergent and textile industries. Enzyme and Microbial Technology 37, 272-277.

Lima ALG, Vinha FNM, Souza DT, Bispo ASR, Bon EPS, Coelho RRR, Nascimento RP. 2009 Aspergillus fumigatus Thermophilic and Acidophilic Endoglucanases. Applied Biochemistry and Biotechnology 155, 321-329.

Liu D, Zhang R, Yang X, Xu Y, Tang Z, Tian W, Shen Q. 2011 - Expression, purification and characterization of two thermostable endoglucanases cloned from a lignocellulosic decomposing fungi Aspergillus fumigatus Z5 isolated from compost. Protein Expression and Purification 79, 176-186.

Mandels M, Andreotti R, Roche C. 1976 - Measurement of saccharifying cellulose. Biotechnology and Bioengineering Symposium Journal 16, 21-33.

Michelin M, Ximenes E, Polizeli MLTM, Ladisch MR. 2015 - Effect of phenolic compounds from pretreated sugarcane bagasse on cellulolytic and hemicellulolytic activities. Bioresource Technology.

Miettinen-Oinonen A. 2004 - Trichoderma reesei strains for production of cellulases for the textile industry. Espoo VTT Publications 500, 1-96.

Miller GL. 1959 - Use of Dinitrosalicylic Acid Reagent for Determination of Reducing Sugars. Analytical Chemistry 31, 426-428.

Moreira LRS, Campos MC, Siqueira PHVM, Silva LP, Ricardt CAO, Martins PA, Queiroz RML, Filho EXF. 2013 - Two $\beta$-xylanases from Aspergillus terreus: Characterization and influence of phenolic compounds on xylanase activity. Fungal Genetics and Biology 60, 46-52.

Moreira LRS, Milanezi NG, Filho EXF. 2011 - Enzymology of Plant Cell Wall Breakdown: An Update, IN: Buckeridge MS, Goldman GH (Eds., 2011) - Routes to Cellulosic Ethanol, : Springer New York, 73-96. 
Naika GS, Kaul P, Prakash V. 2007 - Purification and Characterization of a New Endoglucanase from Aspergillus aculeatus. Journal of Agricultural and Food Chemistry 55, 7566-7572.

Narra M, Dixit G, Divecha J, Kumar K, Madamwar D, Shah AR. 2014 - Production, purification and characterization of a novel GH12 family endoglucanase from Aspergillus terreus and its application in enzymatic degradation of delignified rice straw. International Biodeterioration \& Biodegradation 88, 150-161.

Olofsson K, Bertilsson M, Lidén G. 2008 - A short review on SSF-an interesting process option for ethanol production from lignocellulosic feedstock. Biotechnology Biofuels 1, 1-14.

Parry NJ, Beever DE, Owen E, Nerinckx W, Claeyssens M, Beeumen JV, Bhat MK. 2002 Biochemical characterization and mode of action of a thermostable endoglucanase purified from Thermoascus aurantiacus. Archives of Biochemistry and Biophysics 404, 243-253.

Rawat R \& Tewari L. 2012 - Purification and characterization of an acidothermophilic cellulase enzyme produced by Bacillus subtilis strain LFS3. Extremophiles 16, 637-644.

Ryan SE, Nolan K, Thompson R, Gubitz GM, Savage AV, Tuohy MG. 2003 - Purification and characterization of a new low molecular weight endoxylanase from Penicillium capsulatum. Enzyme and Microbial Technology 33(6), 775-785.

Salles BC, Cunha RB, Fontes W, Sousa MV, Filho EXF. 2000 - Purification and characterization of a new xylanase from Acrophialophora nainiana. Journal of Biotechnology 81, 199-204.

Singhania RR, Saini R, Adsul M, Saini JK, Mathur A, Tuli D. 2015 - An integrative process for bio-ethanol production employing SSF produced cellulase without extraction. Biochemical Engineering Journal 102, 45-48.

Siqueira FG., Siqueira EG, Jaramillo PMD, Silveira MHL, Andreaus J, Couto FA, Batista LR, Filho EXF. 2010 - The potential of agro-industrial residues for production of holocellulase from filamentous fungi. International Biodeterioration \& Biodegradation. 64, 20-26.

Tambor JH, Ren H, Ushinsky S, Zheng Y, Riemens A, St-Francois C, Tsang A, Powlowski J, Storms R. 2012 - Recombinant expression, activity screening and functional characterization identifies three novel endo-1,4- $\beta$-glucanases that efficiently hydrolyse cellulosic substrates. Applied Microbiology and Biotechnology 93(1), 203-214.

Tejirian A \& Xu F. 2010 - Inhibition of Cellulase-Catalyzed Lignocellulosic Hydrolysis by Iron and Oxidative Metal Ions and Complexes. Applied Microbiology and Biotechnology 76(23), 7673-7682.

Trinder P. 1969 - Determination of glucose in blood using glucose oxidase with an alternative oxygen acceptor. Annals of Clinical Biochemistry 6, 24-25.

USDA. 2015 - United States Department of Agriculture. http://www.ers.usda.gov/topics/crops/soybeans-oil-crops.aspx (accessed 22 Jan 2015).

Vohra RM, Shirkot CK, Dhawan S, Gupta KG. 1980 - Effect of Lignin and Some of its Components on the Production and Activity of Cellulase(s) by Trichoderma reesei. Biotechnology and Bioengineering 22, 1497-1500.

White TJ, Bruns T, Lee S and JW Taylor. 1990- Amplification and direct sequencing of fungal ribosomal RNA genes for phylogenetics. IN: Innis, M., DH Gelfand, JJ Sninsky, and T.J. White (Eds.) - PCR Protocols: A Guide to Methods and Applications 315-322.

Xiang L, Li A, Tian C, Zhou Y, Zhang G, Ma Y. 2014 - Identification and characterization of a new acid-stable endoglucanase from a metagenomic library. Protein Expression and Purification 102, 20-26.

Ximenes E, Kim Y, Mosier N, Dien B, Ladisch M. 2010 - Inhibition of cellulases by phenols. Enzyme and Microbial Technology 46, 170-176.

Ximenes E, Kim Y, Mosier N, Dien B, Ladisch M. 2011 - Deactivation of cellulases by phenols. Enzyme and Microbial Technology 48(1), 54-60. 